\title{
The African Verbal Genre as Literature and Performance
}

\author{
Andrew Bula (Corresponding author) \\ Centre for Foundation \& Interdisciplinary Studies, Baze University, Abuja, Nigeria \\ Department of English and Literary Studies, University of Nigeria, Nsukka, Nigeria \\ Brix Academy, Abuja, Nigeria \\ Email: andrew.bula@bazeuniversity.edu.ng \\ ORCID: https://orcid.org/0000-0002-9964-0934
}

Received: $11 / 04 / 2020$

Accepted: 22/06/2020

Published: 01/07/2020

Volume: 1 Issue: 2

How to cite this paper: Bula, A. (2020). The African Verbal Genre as Literature and Performance. Journal of Critical Studies in Language and Literature, 1(2), 20-25

DOI: https://doi.org/10.46809/jcsll.v1i2.7

Copyright $(2020$ by author(s) and Global Talent Academy Ltd. This work is licensed under the Creative Commons Attribution International License (CC BY 4.0).

http://creativecommons.org/licenses/by/4.0/

\section{(c) $(0)$}

\begin{abstract}
There is a view that the African verbal genre is not literature and its nature does not include bodily performance; it belongs to sociology and not literature because literature is the art that is written while African verbal genre is presented orally. Thus, the present study aims to demonstrate that, despite its oral nature, the African verbal genre is both literature and oral performance that includes bodily performance and that its literary and performative constituents synergize to achieve the purpose of the genre.
\end{abstract}

Keywords: Verbal Genre, Literature, Performance, Sociology, Tiv, Creativity

\section{Introduction}

The inevitable question that arises: Is there a link between literature and sociology? Put differently, shouldn't 'funeral poetry' be regarded as poetry and therefore literature simply because it is not written and does not exist in the formal environment of school? Indeed, the answer is that there is a connection between literature and sociology (or society).The eminent Kenyan novelist and revolutionary, Ngugi wa Thiong'o, rightly subscribes to this viewpoint when he contends that "literature does not grow or develop in a vacuum; it is given impetus, shape, direction and even area of concern by social, political and economic forces in a particular society" (Killam, 123).

But that is only an instance of the misconception that the African 'verbal genre' is not 'literature'. In Oral Traditions and the Verbal Arts, Ruth Finnegan, a long time champion of oral literature, scripts that "some argue that it is self-contradictory (how can 'literature', etymologically implying writing, be unwritten?)" (8). This is why the Ugandan scholar and theorist, Pio Zirimu, made a fine case to change the term 'oral literature' to 'orature' so as to safely bring the controversy about nomenclature to a close. Nonetheless, 'oral literature' remains the most commonly utilized term, with synonyms as 'verbal genre', 'verbal art', 'oral art', 'oral genre', and 'unwritten literature'. Accordingly, Anagrams, Parodies, Puns, Riddles, and Tongue Twisters are examples of the verbal genre, whereas Masquerades, Dances, Hand Drums, Flutes, and Signal gongs are neat exemplars of non-verbal genres and therefore of the umbrella term 'oral literature'. However, the terms 'oral' and 'literature' remain contradictory. Finnegan herself has reservations about the matter as she reasons in a chapter of Oral Literature in Africa headed "The "Oral' Nature of African Unwritten Literature" that terminologies like "folk art", "folklore", or "verbal art" are more suitable designations than those of "oral literature", "unwritten literature", "popular" and "traditional 
literature" and then remarks at the end of it that "oral literature is only one type of literature, a type characterized by particular features...But for all these differences, the view that there is no essential chasm between this type of literature and the more familiar written forms is a basic assumption throughout this book".(Oral Literature in Africa, ch. 1) In this critical inquiry, the view taken is that although there is a big gulf between the verbal genre and written literature on many grounds, there are nonetheless striking similarities between the two which is, in fact, why it can complimentarily be regarded as literature - that is, oral literature or the verbal genre.The performance of the African verbal genre, on its part, is viewed as being exclusive of facial expressions, gestures, dance, and so on. Accordingly, Finnegan has diagnosed the problem as one of "concentration on words" (Oral Literature in Africa, ch. 1) after she accounts for the different sorts of components which together constitute an oral performance:

all the variegated aspects we think of as contributing to the effectiveness of performance in the case of more familiar literary forms may also play their part in the delivery of unwritten pieces - expressiveness of tone, gesture, facial expression, dramatic use of pause and rhythm, the interplay of passion, dignity, or humour, receptivity to the reactions of the audience, etc., etc. ...Unfortunately it is precisely this aspect which is most often overlooked in recording and interpreting instances of oral literature. This is partly due, no doubt, to practical difficulties; but even more to the unconscious reference constantly made by both recorders and readers to more familiar written forms. This model leads us to think of the written element as the primary and thus somehow the most fundamental material in every kind of literature - concentration on the words to the exclusion of the vital and essential aspect of performance. It cannot be too often emphasized that this insidious model is a profoundly misleading one in the case of oral literature. (Oral Literature in Africa, ch. 1)

In this article, the sense in which the term 'verbal genre' is deployed is not restricted to words alone, but also includes "all the variegated aspects we think of as contributing to the effectiveness of performance" (Oral Literature in Africa, ch. 1). This paper also shows how the literary and performative aspects of the African verbal genre unify to realize the objective of the genre.

\section{The African Verbal Genre as Literature}

Various positions have been taken as to whether the African verbal genre should be considered literature or not; with, as detailed earlier, some arguing that etymologically 'literature' as a term means writing or something that is written and so based on its appellation, the 'oral genre' does not fit in as literature. According to Finnegan, "the fact...that oral art depends for its creation on the actual (and thus ephemeral) performance of it seems to some to disqualify it from true literary status" (Oral Literature in Africa, ch.1). Correspondingly, N.K. Chadwick has written that: "In 'civilized' countries we are inclined to associate literature with writing; but such an association is accidental...Millions of people throughout Asia, Polynesia, Africa and even Europe who practice the art of literature have no knowledge of letters. Writing is unessential to either the composition or the preservation of literature. The two arts are wholly distinct". (qtd. in Finnegan, ch. 1)

Interestingly, the inference which can be drawn from Chadwick's viewpoint and Finnegan's above is that although the two art forms (the verbal genre and literature) are distinct in terms of their mediums, they are nonetheless strikingly identical as regards their content - that is, their reliance on 'actuality' for artistic creations. Thus, the grossly inadequate definition of literature which some people often mouth in the course of a small talk about literature, that "literature is life" probably has some validity. Because its creation is premised on reality and it purposes to improve human life, to mention a few. And if as Chadwick reflects, 'writing' is only accidental to 'literature', then it follows that the 'oral' medium is equally accidental to 'practical creativity' or 'artistic reality', not 'literature' which is, after all said and done, the conventionally acceptable tag for written creativity. What, then, might be the appropriate label for oral creativity? Again, to return to the aforementioned, 'oral literature' can among other designations complimentarily conveniently serve the purpose. True, written literature outclasses it by far as it is sophisticated whereas oral literature is not. But, yes, oral literature is literature because aside its lack of depth that is; the absence of bulkiness, of complex figures of speech, of exploration of the recesses of human nature and the life of the modern individual person - aside all of these and more, it shares two core elements with written literature and that is the fact of the aesthetic and educative qualities which it offers.

Further, an oral song is like a written poem just as an oral narrative is similar to a novel or short story. In other words, even before Africans were formally educated and knew how to write, creativity was a part of their lives. For instance, poetry was expressed by the singing of songs when women were fishing, or a man was farming, or during a marriage ceremony and when someone died while prose fiction was ever present in the moonlight tales told around a burning torch or under the brilliance of the moonlight at night.

As for drama, a case in point of its existence was in the Kwagh-hir theatre among the Tivs of Central Nigeria. As Iyorwuese Hagher aptly captures it in his marvellous book, The Kwagh-hir Theatre: A Metaphor of Resistance, "the Kwaghhir theatre derives from the story-telling performances of Tiv people. Both the theatre and story-telling events are interchangeable and synonymously called Kwagh-hir, the supernatural tales, or Kwagh-alom, things about the hare. The Kwagh-hir story telling event is the focal point of Tiv theatre" (12). Further, Hagher elucidates that "the Kwagh-hir is an event, which provides secular enactment, education, and socialization through the enactment of past and contemporary events by human performers, using puppets and masquerades" (17). It is worthy of lavish praise what Hagher has gone on to achieve in the appendix section of his work, as he has laboured and made available a list of acted plays in the history of Kwagh-hir 
from 1987 to 2003, ranging from its nature as either puppets or masquerades or as a hybridization of both. By the same token, since culture is a people's way of life, and the Tiv people have been existing before and after the period of Hagher's documentation of their theatrical practices; since they have been around before and after their encounter with the ways of the white man, it stands to reason that drama has being through and through part of their lives, even if only fragments of the practice of Kwagh-hir theatre remains today.

A discussion of the African verbal genre as literature does necessarily implicate the question of the translation and transcribing of it to, as well as the exploitation of it in, written literature. In other words, another parameter by which the African verbal genre can be regarded as literature resides in the fact that it is usually translated and transcribed from its oral nature onto paper, as a consequence of which it becomes written literature, as well as the deployment of it in written literature. For example, an oral work can be transcribed onto paper. This is what Moses Tsenongu, a leading scholar in the study of Tiv oral literature, has accomplished in his very informative article, Creativity and Disease: Tiv Oral Poets and Poetic Self-diagnosis, in which he transcribes as well as translates an oral religious poem of a great Tiv oral poet, Ityavgyer Fate, that reads in part as follows:

\author{
Ican I yange se iember shin bo tar ne ga \\ Suffering does not forbid our joy in this bad world \\ Yesu sen va yima se, se ember! \\ Jesus has come and saved us, we rejoice!
}

\author{
A hemba ku man ican. \\ He overcame death and suffering. \\ Ma M um ityou \\ I would have had bushy hairs on my head \\ (The Ker Review, 93)
}

In a similar fashion, there can also be a translation of a collection of oral narratives. This is what the distinguished experimentalist Ugandan poet, Okot p'Bitek, has done by translating folktales from his native Acholi into English, the result of which is the book Hare and Hornbill. Of its exploitation in written literature, Chinua Achebe's adroit handling of oral literary materials in Things Fall Apart and Arrow of God readily comes to mind. In these works, there are the uses of anecdotes, proverbs, folktales, and folk songs. This fact is given a nod and amplified by Okpewho in a truly enlightening study, Oral Literature and Modern African Literature, in which he painstakingly provides ample illustrations of the application of oral literary stuffs in written literatures as Achebe's Things Fall Apart and Arrow of God; p'Bitek's Song of Lawino, and hints at the same thing in Efua Sutherland's The Marriage of Anansewa, Sembene Ousmane's The Money Order amidst the work of other writers like Wole Soyinka and Ayi Kwei Armah. In fact, his opening statement to the article reveals much:

There has $[\ldots]$ been an increasing tendency on the part of modern African writers to identify with the literary traditions of their people in terms both of content and of technique. The reason is not far to seek. For a long time before African nations won political independence from their European colonizers, African culture was mis-understood and misrepresented. Words such as savage and primitive were used in describing it and[...] the literary or artistic quality of the oral literature was underplayed and undermined by foreign scholars who had little or no feeling for the languages and the attitudes in which that literature was expressed. It was only inevitable that, when these African nations won their independence from foreign domination, they undertook to demonstrate that Africa has had, since time immemorial, traditions that should be respected and a culture to be proud of. As far as the creative writers are concerned, the main offshoots of this program have been to collect and publish texts of the oral literature of their people as practiced by them over time and to use that literature as a basis for writing original works... (African Literature: An Anthology of Criticism and Theory, ch. 11)

While there is nothing at all wrong with this statement, it should be pointed out that the modern African writers and their writing project cited in the quotation belong to an earlier generation - the generation of Achebe. What this means is that modern writers not of that era as Ben Okri, Chimamanda Ngozi Adichie, Femi Osofisan, Tess Onwueme, Niyi Osundare, and many others may employ oral literary materials in their works with a different mindset. In fact, even those of the same period in question who are still alive and writing today may not have that cast of mind. Soyinka for one has never associated himself with that program, worthy though it is. But in his works there is abundant evidence of the use of oral stuffs, indicating clearly that the practice can essentially be a matter of creativity - that is, the utilization of local colour to achieve verisimilitude.

Nor is this shying away from a defence of African culture (oral literature inclusive, and especially) against such foul comments made about it as "savage" and "primitive" and the prejudiced attitude of "underplaying" and "undermining" its oral literature. Indeed, it is not only Okpewho who has decried this. Finnegan also bemoans similar derogatory perceptions of the African verbal genre and dismisses them as "assumptions" that are invalid. She writes: "The concept of oral literature is an unfamiliar one to most people brought up in cultures which, like those of contemporary Europe, lay stress on the idea of literacy and written tradition. In the popular view it seems to convey on the one hand the idea of mystery, on the other that of 
crude and artistically undeveloped formulations. ...neither of these assumptions is generally valid". (Oral Literature in Africa, ch. 1) Further, she complains that "a related assumption was that oral literature (often in this context called 'folklore') was relatively undeveloped and primitive; and this derogatory interpretation was applied to oral literature both in completely non-literate societies and when it coexisted with written literary forms in 'civilized' cultures" (Oral Literature in Africa, ch. 1). Like Finnegan, let it also be known here that these views about the African verbal genre are greatly misperceived and unfair, to say the least because the so-called "undeveloped and primitive" African societies had things, including oral literature, that were sufficient onto their needs. Oral literature, for instance, was a vehicle through which African natives interpreted their own world. With the coming of formal education and with it the practice of writing, there is, however, no harm in yoking together oral and written literatures, because the world has now become unitary.

And then, again, there is the question of the African verbal genre being strictly considered as sociology and not literature. Okpewho, though aware of the shaky bond between both, understands nevertheless that there is a connection between literature and sociology and that the oral genre cannot strictly be said to be sociology, which is why he utilizes the term "collaboration" in the following: "In this study of oral performance, will the collaboration between sociological and literary interests ever realize its full potential?" (The Oral Performance in Africa, 5) But, further, Okpewho suspects that the oral genre will remain in the province of sociological studies no matter how much it serves the purpose of literature. Hence, he voices that "one gets the impression that, whatever concessions the "ethnography of performance" (to use Bauman's felicitous phrase) makes to the interests of art, it is in the final analysis unwilling to abandon its home base in sociological investigations" (5). Logically, the ultimate issue here should not be about the "ethnography of performance" (5) or the study of the verbal genre serving the delight of art and yet being disinclined to leave its roots in sociological studies. Rather, it should be about the fact that sociology and literature have a relationship, namely that the one furnishes the other with its materials for the latter's production.

\section{The African Verbal Genre as Performance}

Undoubtedly, the African verbal genre is not only literature; it is also performance. True, most often than not, at the mention of the term "performance" the sense that first comes to mind is one of dramatic enactment or gesturing to the exclusion of oral rendition. However, with regard to the performance of the African verbal genre particularly, oral performance is, as noted before, viewed to differ from bodily movements like gesturing, facial expressions, clapping, and dancing- something which Finnegan rationalizes to be as a result of "concentration on the words to the exclusion of the vital and essential aspect of performance" (Oral Literature in Africa, ch. 1). Indeed, if everyone is to go by the tag of "African verbal genre' that speaks to its oral nature, oral performance would be through and through about words. But labels are not always helpful! Therefore, use of the nomenclature beyond the sense of the words which it carries is a more useful approach. Finnegan is, thus, absolutely correct when she exercises the thinking that,

The significance of performance in oral literature goes beyond a mere matter of definition: for the nature of the performance itself can make an important contribution to the impact of the particular literary form being exhibited. This point is obvious if we consider literary forms designed to be delivered to an audience even in more familiar literate cultures. If we take forms like a play, a sermon, 'jazz poetry', even something as trivial as an after-dinner witty anecdote -in all these cases the actual delivery is a significant aspect of the whole. Even though it is true that these instances may also exist in written form, they only attain their true fulfilment when actually performed. (Oral Literature in Africa, ch. 1)

The importance of bodily performance to oral art is actually very immense. But this is not to say that all oral performances must involve gestures and dance, to mention a few. Among the Tivs, some oral poets have sung their songs without accompanying them with gestures or dance or other activities besides singing. And whereas it is true that other Tiv poets have sang as well as danced or done other bodily movements, this shows clearly that whatever style adopted is a matter of personal taste and choice. Finnegan provides more insight into this in the following:

The detailed way in which the performer enacts the literary product of his art naturally varies both from culture to culture and also among the different literary genres of one language. Not all types of performance involve the extremes of dramatization. Sometimes indeed the artistic conventions demand the exact opposite - a dignified aloof bearing, and emphasis on continuity of delivery rather than on studied and receptive style in the exact choice of words. (Oral Literature in Africa, ch. 1)

In the conclusion of a thoroughly researched article, The Five Ages of Tiv Oral Poetry, a work in which he expertly does a grouping of Tiv oral poets, Tsenongu establishes that "Mtsem Acaver of Mbakor and Anyam Ayua of Mbagba, for instance, belonged to the Bam Ginde age calendrically speaking but they were not dancer-poets or poet-musicians" (96-97). From this conveyed data, there are attractive bits of information which have a bearing on the foregoing, namely the words "dancer-poets" and "poet-musicians"- terms which signify that there are oral poets-cum-dancers, oral poets qua musicians, and oral poets who just sing, that is, who only deal with words and nothing more. In other words, the last categories of oral poets mentioned here are those who have composed their songs and sung them with no garnishments or embellishments of any kind except, perhaps, that of their voices.

Thus, the significance of oral performance, of the African verbal genre, or of oral literature cannot be over-emphasized. It is creativity in action, and it involves such components as words, singing, the use of other musical instruments apart from 
voice, and dancing. In a sense, 'oral performance' also entails making 'literature' come alive when, say, Ola Rotimi's play is put on stage.

However, there is yet another fascinating element to this whole discourse about the African verbal genre as literature and performance which remains to be dealt with. The matter is this: How do the literary and performative appurtenances of the African verbal genre fuse to achieve the purpose of the art form? To answer this question, one has to first of all consider what makes up the 'literariness' of the African verbal genre. Simply put, what are the 'literary' indices in the oral genre?

The first is that in an oral performance there is usually some dint of literary language exploited. This means that there is normally some amount of literary expressions in it. Consider, for example, this oral rendition of an extraordinary Tiv poet, Amee Ijorpo, as transcribed and translated by Tsenongu:

Ter Aondu nam ican yam ka ken uya je ee;

The Lord God apportioned my suffering for me from My womb-days ee;

Shi nam mliam ma vaan; $M$ vaa ior gege ashe pirim...

He also apportioned mourning for me; how I have

Mourned for people till my eyes are blind [with tears]...

(The Ker Review, 96)

In the transcription of the song shown, it is undeniably evident, especially to a native speaker of the Tiv language like the present writer that there are the presences of alliterations and rhythms in the transcribed oral piece, as in the words "nam mliam ma vaan" and "gege". (The focus here is quite rightly on transcription because it is common knowledge that however close to the original translation of a literary stuff may be; the earner language cannot, and so does not, replicate all the nuances of meaning, expressions and their accompanying fluidity, and the emotional feel inherent in the donor language. Better then to embrace transcription - which is neither the actual substance). In a similar vein, Tsenongu lauds the work of Fate, the great Tiv oral poet referenced earlier, in the following terms: “...it is Fate's creative poetics that attracted people so massively. His generous exploitation of the figurative wealth of Tiv language in presenting his messages could not but captivate his audience. The songs were robust with proverbial wisdom, idiomatic pregnancy and imagistic vivacity" (The Ker Review, 91) Now, from the pair of examples given, all taken from Tsenongu's accounts of two oral Tiv poets, it is obvious that the literary and the performative aspects of the African verbal genre which together coalesce to accomplish the aim of the genre resides at once in the literary and performative use of language to express it, especially when an oral poet is adept at this.

Accordingly, and again, whereas what constitutes the literariness of the African verbal genre is the utilization of literary devices like alliteration, rhythm, proverbs, idioms, and imagery, the performative ingredient of the concerned art form lies in singing accompanied by gesturing, facial expressions, dancing, and so on. This is one of the ways in which the literary and performative components of the African verbal genre combine to achieve the purpose of the art.

\section{Conclusion}

Taken together, the African verbal genre is both literature and performance that includes bodily movements. On the one hand, it is literature because although its nature is first and foremost oral, it resembles written literature not only in its outlook but in the educative and aesthetic qualities it provides, and the all-important fact that it is adopted for use in written literature so that, being removed from its orality, it has become part and parcel of written literature - with a dual nature - the original and the acquired. This is what is meant by complementarity, which is progressive, instead of the continual harping on the etymological nomenclature of the term 'literature' as 'writing' which is retrogressive. In fact, as Chadwick's line of reasoning goes, writing is accidental to literature - or 'creativity', since the term 'literature' is controversial! The thinking, therefore, that literature is life probably has its points. But it does not signify that literature is entirely sociology, especially the kind known as 'oral literature'. The two domains simply have a connection.

On the other hand, oral performance is not only about words and singing; it includes music making other than with voice, like gesturing, dancing, facial expressions, etc. However, it can also be essentially about words and singing. It all depends on personal choice and taste and, in some cases, different cultural conventions and literary forms in a language, as Finnegan notes. In short, the African verbal genre is indeed both literature and performance which includes bodily movements, and how its literary and performative constituents unite to fulfil the purpose of the genre is fundamentally in how an oral poet exploits literary devices or figures of speech, some of which are: simile, metaphor, alliteration, rhythms, and proverbs, coupled with some performative characteristics as singing itself (which sometimes occur side by side with); gesturing, facial expressions, clapping, and dance, all of which have already been isolated in this critical enterprise.

\section{References}

Finnegan, R. (2012). Oral Literature in Africa. United Kingdom: Open Book Publishers 
---. (2005). Oral Traditions and the Verbal Arts: A Guide to Research Practices. New York: Taylor \& Francis e-Library Hagher, I. (2003). The Kwagh-hir Theatre: A Metaphor of Resistance. Ibadan: Caltop Publications

Killam, G.D. (1984). The Writing of East Africa. London: Heinemann

Okpewho, I. (2007). Oral Literature and Modern African Literature. Quayson, A. and Tejumola O. eds. African Literature: An Anthology of Criticism and Theory. USA, 83-91.

--- (2003). The Study of Performance. Okpewho, I. ed. The Oral Performance in Africa. Spectrum Books Limited, 1-20 Tsenongu, M. T. (2007). The Five Ages of Tiv Oral Poetry. The Ker Review 3 (2), 72- 99

--- (2009). Creativity and Disease: Tiv Oral Poets and Poetic Self-diagnosis. The Ker Review 5 (1\&2), 85-101 